\title{
Effects of Disability and Self-care Agency on the Activities of Daily Living in Patients with Essential Tremor
}

\author{
Esansiyel Tremorlu Hastalarda Yeti Yitimi ve Öz Bakım Gücünün Günlük Yaşam \\ Aktiviteleri Üzerine Etkisi
}

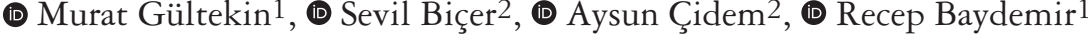 \\ ${ }^{1}$ Erciyes University Faculty of Medicine, Department of Neurology, Kayseri, Turkey \\ 2Erciyes University Faculty of Health Sciences, Division of Nursing, Kayseri, Turkey
}

\begin{abstract}
Objective: Essential tremor (ET) is the most common movement disorder in the general population. Approximately, $90 \%$ of patients have upper extremity tremors. Patients with ET generally have a problem in motor control and some have serious problems in eating, drinking, writing, and other activities of daily living (ADL). Thus, ET may cause disability and self-care problems in their lives. Recent studies showed that ADL was impaired in $73 \%$ of patients. This study aimed to determine the effects of disability and self-care agency on ADL in patients with ET.

Materials and Methods: This study includes 50 patients with ET. Brief disability questionnaire, self-care agency scale, Katz index of independence in ADL, and Fahn Tolasa Marin tremor scale were evaluated in the patients.

Results: Among all patients, 58\% ( $\mathrm{n}=29)$ were female. The mean age of patients was 62.1 years. In addition, $72 \%$ of patients had hand tremors. More than $52 \%$ of patients had stage 2 diseases according to the Fahn Tolasa Marin tremor scale. Disability was detected in 62\% of patients. In general, the mean disability scores were significantly higher in female patients compared to males. A positive correlation was found between disability and ADL. Moreover, a significant relationship between self-care agency and ADL was found.

Conclusion: Our study shows that disability increases as the stage of the disease progress. In addition, as the disability due to ET becomes more severe, the selfcare agency of patients decreases. Moreover, their dependence on ADL has been observed.
\end{abstract}

Keywords: Essential tremor, self-care, activities of daily living

$\ddot{\mathbf{O z}}$

Amaç: Esansiyel tremor (ET), genel popülasyonda en sık görülen hareket bozukluğudur. Hastaların \%90'ı ellerinde ve kollarında tremor yaşarlar. ET'li hastalar genelde motor işlevlerin kontrolünde problem yaşarlar. Bazıları yeme, içme, yazma gibi günlük yaşam aktivitelerinde (GYA) ciddi problemlerle başa çıkmak durumunda kalırlar. Dolayısıyla, ET hastalarda yeti yitimine sebep olabilir ve öz bakım problemlerine yol açabilir. Son zamanlarda yapılan çalışmalarda ET’li hastaların \%73'ü GYA'da zorluklar yaşadığını bildirmişlerdir. Bu çalışmanın amacı, ET’li hastalardaki yeti yitimi ve öz bakım gücünün GYA üzerine etkilerini araştırmaktır.

Gereç ve Yöntem: Araştırmaya 50 ET’li hasta dahil edildi. Hastalara kısa yeti yitimi anketi, öz bakım gücü ölçeği, Katz GYA indeksi ve Fahn Tolasa Marin tremor ölçeği uyguland1.

Bulgular: Hastaların \%58’i (n=29) kadın katılımcılardan oluştu. Hastaların yaş ortalaması 62,1 idi. Hastaların \%72'sinde ET ellerdeydi. Hastaların yarısından fazlasının (\%52) Fahn Tolasa Marin tremor ölçeğine göre 2. seviyede oldukları tespit edilmiştir. Hastaların \%62'sinde yeti yitimi mevcuttu. Genel olarak erkeklerin aksine, ortalama yeti yitimi skorları kadınlarda anlamlı olarak daha yüksekti. Ayrıca, yeti yitimi ile GYA arasında pozitif bir ilişki bulundu. Ek olarak, öz bakım gücü ile GYA arasında da anlamlı bir ilişki raporlandı.

Sonuç: Çalışma gösteriyor ki, hastalığın düzeyi arttıkça, yeti yitimi skorları da artıyor. Ayrıca, ET’li hastaların yeti yitimi ağırlaştıkça, hastaların öz bakım güçleri düşüyor. Buna ek olarak, kişilerin GYA'ya bağımlılı̆̆ da tespit edilmiştir.

Anahtar Kelimeler: Esansiyel tremor, öz bakım gücü, günlük yaşam aktiviteleri

Address for Correspondence/Yazışma Adresi: Murat Gültekin Assoc. MD, Erciyes University Faculty of Medicine, Department of Neurology, Kayseri, Turkey Phone: +90 3522076666 E-mail: gultekin@erciyes.edu.tr ORCID: orcid.org/0000-0002-0609-4269

Received/Geliş Tarihi: 22.12.2020 Accepted/Kabul Tarihi: 13.08 .2021

${ }^{\circ}$ Copyright 2021 by Turkish Neurological Society

Turkish Journal of Neurology published by Galenos Publishing House. 


\section{Introduction}

Essential tremor (ET) is one of the most common movement disorders worldwide, which is characterized by postural and/ or kinetic tremor (1). ET is seen in approximately $1-6 \%$ of the population (2). The disease is characterized by postural and/or kinetic tremors with a frequency of $4-12 \mathrm{~Hz}$. While the tremor frequency decreases with time, its amplitude generally slightly increases. Tremor localization widely varies among patients. Tremor is observed in the upper extremities in approximately $90 \%$ of patients, $30 \%$ were in the head, $20 \%$ in the voice, $10 \%$ in the chin and face, and $10 \%$ in the lower extremities (3).

ET affects the motor control of the hands. Especially, it causes serious problems in daily activities such as eating, drinking, and writing and results in loss of workforce and disability (4). Treatment options in ET are not curative; however, tremor is partially reduced in only $50 \%$ of patients and unfortunately, treatment is ineffective in $30-50 \%$ of patients. This situation adversely affects the patients' ability to perform their activities of daily living (ADL). ET is generally benign, and studies show that $73 \%$ of patients have impaired ADL (5). Therefore, it can cause serious disability that cannot be called benign.

Disability is defined as the limitation or loss of the ability to perform an activity within the limits or manner that is considered normal for the person (6). Physical disability due to illness negatively affects the self-care power of individuals. Activities are those performed by the individual to maintain his/her life, whereas health and well-being are defined as self-care, and the ability to perform these activities is expressed as self-care agency. Individuals with ET vary according to tremor severity; however, they need partial or complete help in maintaining their care, and self-care is a priority problem.

ADL defined as the activities performed by healthy individuals to sustain their lives, are activities such as ensuring environmental safety, communication, eating, drinking, excretion, personal hygiene, and mobility $(7,8)$. ET causes varying degrees of disability in mobility and functional activities, thus these individuals need help from others. This situation makes individuals more or less dependent.

Motor symptoms, such as balance problem and gait disturbance, were revealed to have negative effects on ADL in patients with ET, and that the presence of symptoms, such as cognitive impairment, anxiety, and depression, are added to motor symptoms, and the ineffectiveness of the drugs used in the treatment of ET have a direct negative impact on the quality of life of patients $(9,10)$.

In our country, insufficient data in examining the disability of patients with ET and the effect of self-care agency on the ADL was remarkable, thus such studies were thought to be important in the planning and rehabilitation of the care for patients with ET. This study aimed to determine the effects of disability and selfcare agency on the ADL of patients with ET.

\section{Materials and Methods}

\section{1- Participants}

The population of the study consisted of all individuals over the age of 18 years who were admitted to the Erciyes University Faculty of Medicine Hospital in 1 year and were diagnosed with ET and agreed to participate in the study. Permission was obtained from Erciyes University Clinical Research Ethics Committee before conducting the study (decision no: 2017/429, date: 15.09.2017). All participants were informed about the scope of the study and informed consent forms were obtained. Data were collected by the researchers using a face-to-face interview technique and from patient records. Answering a questionnaire/scale took an average of $15-20 \mathrm{~min}$.

\section{2- Patient Information Form}

The 24-question form that was developed by the researchers in line with the relevant literature (1-4) consists of three parts: "sociodemographic characteristics," "information about the disease," and "tremor assessment."

\section{3- Brief Disability Questionnaire (BDQ)}

The BDQ is a short questionnaire that was developed by the World Health Organization that evaluates physical and social disability (11). Its validity, reliability, and Turkish adaptation were made by Kaplan (12). Kaplan (12) calculated the reliability coefficient of BDQ as 0.91. The questionnaire was developed based on the questions about disability in the general health screening short form, which consists of 11 items that question the physical and social disability in the BDQ, in which the last 1-month period is evaluated. Scores of 0-4 indicate no disability, 5-7 mild disability, 8-12 moderate, and 13 and above severe disability (12).

\section{4- Self-care Agency Scale (SCAS)}

The scale used to measure an individual's self-care ability or self-care agency was developed by Kearney and Fleicher (13), which consists of 43 items. The validity and reliability study of the scale for the Turkish population was carried out by Nahcivan (14) in 1993 and the Cronbach alpha coefficient was found to be 0.89 . The maximum score on the scale is 140 . Scores close to 140 show an increased self-care agency score (14).

\section{5- The Katz Index of Independence in ADL (KATZ)}

It was developed by Katz et al. (15) in 1963. The Turkish translation was done by Yardımc1 (16), and the reliability coefficient of the index was found to be 0.84 . It consists of expressions for 6 ADLs, including information about bathing, dressing, toileting, mobility, excretion, and feeding. In the index, 0-6 points indicate that the patient is dependent, 7-12 points semi-dependent, and 13-18 points independent.

\section{6- Fahn Tolosa Marin Tremor Scale}

The Fahn Tolosa Marin Tremor Scale was developed by Fahn et al. (17). The scale was later revised (18). The scale assesses resting, postural, and action tremors in specific areas. It consists of 3 parts, with points that can be taken for each part that vary between 0 and 4. The inter-practitioner internal consistency score of the scale, which did not have a Turkish version, was reported as $\mathrm{p}=0.97$ in the international reference (18).

\section{Statistical Analysis}

The data were evaluated in the Statistical Package for the Social Sciences 21.0 package program. In the statistical evaluation, the mean and percentage values of the data were calculated, and correlation analyzes were made between the scales. The OneWay analysis of variance test was used to evaluate the difference between the subgroups, such as gender, marital status, place of 
residence, employment, presence of a caregiver, and features of the caregiver. Since the data did not show a normal distribution, the difference between the subgroups, such as age, education level, the people living with, income status, ability to take care of themselves, tremor staging, tremor type, and disability status was evaluated according to the scales with the Kruskall-Wallis analysis of variance test.

\section{Results}

The mean age of patients with ET $(n=50)$ who are included in the study was $62 \pm 18.7$ years, and $58 \%$ of patients were female. Of the participants, $38 \%$ were in the age group of 60-69 years, $22 \%$ in 70 years or over, $16 \%$ in $18-29$ years, $12 \%$ in $40-49$ years, $8 \%$ in 50-59 years, and $4 \%$ in 30-39 year. Of the participants, $42 \%$ were primary school graduates, $38 \%$ were secondary school graduates or above, $12 \%$ were illiterate, and $8 \%$ were literate. Of the participants, $70 \%$ were married, $44 \%$ lived with their spouse and children, $82.0 \%$ did not work in any job, $72 \%$ had medium income, and $86 \%$ lived in the city/urban area, whereas $14 \%$ lived in the rural area. Of the patients, $82 \%$ stated the inability to meet their self-care, $8 \%$ were partially, and $10 \%$ were fully met. No one took care of $80 \%$ of participants, whereas $20 \%$ was taken care of by someone. The caregiver in $90 \%$ of patients $(n=10)$ was a family member, whereas in $10 \%(n=1)$ was not a family member (Table 1).

The mean disease duration of patients was $8.50 \pm 5.0$ years, wherein $56 \%$ were in stage II according to the Fahn Tolosa Marin tremor scale. The most common tremor type was in the hands of $72 \%$ of patients, whereas $38 \%$ did not have a disability (Table 2).

The mean BDQ score of patients with ET was found to be $2.96 \pm 0.19(0-22)$, mean SCAS score was $110.72 \pm 25.70(0-140)$, and mean KATZ score was $17.36 \pm 1.38(0-18)$.

A positive and weakly significant relationship was determined between disability and ADL and a moderately significant positive relationship between self-care agency and ADL $(r=0.346 ; p<0.05)$ (Table 3).

A statistically significant difference was found between the descriptive characteristics of the patients and their BDQ, SCAS, and KATZ scores; between the age group and BDQ score; and between income status and BDQ, SCAS, and KATZ scores. Individuals with very poor income status were determined to have a high BDQ mean score and low SCAS and KATZ mean score. Educational level, marital status, the people living with, working status, and place of residence did not affect the BDQ, SCAS, and KATZ scores (Table 1).

The status of providing personal care and who provided care created a significant difference in BDQ and KATZ scores (Table $1)$. The mean score of BDQ of individuals who partially met or could not meet their care was higher than those completely met.

The disease stage affected the mean BDQ score, whereas the type of tremor did not affect the BDQ, SCAS, and KATZ scores. Individuals with stage IV diseases had higher mean BDQ scores. A significant difference was found between the severity of disability and BDQ, SCAS, and KATZ scores (Table 2). Individuals with a severe disability had a higher mean BDQ score and a lower SCAS and KATZ mean score.

\section{Discussion}

This study revealed that as disability worsened due to ET, patients' self-care agency decreased and their dependency increased in ADL. However, the second main finding was that disability increased as the disease stage progressed. Generally, the mean disability in women was found to be significantly higher than that in men.

ET negatively affects the patients' ADL and participation in society, thus their quality of life may decrease ET. Self-care agency is accepted as a protective factor against depression, vulnerability, decreased cognitive functions, and housebound. Increasing self-care agency, self-management skills, and regular exercise in chronic diseases reduce the psychological, cognitive, social, and physical frailty among older adults (19). A recent meta-analysis study by Soysal et al. (20) revealed a consistent Two-Way relationship between frailty and depression in elderly individuals. A cohort study conducted by Jang et al. (21) observed that elderly individuals living in rural areas had more frailty and health conditions related to aging compared to those in urban areas. Self-care agency is an individual's ability to adhere to one's self-care in behavioral and cognitive terms and is accepted as a predictive factor. Therefore, increasing self-care agency is necessary for chronic disease management in elderly individuals (19).

Some patients with ET may have increased disease severity. Concerning this, ADLs are significantly affected negatively, and increased disease severity causes disability. Individuals need a certain level of self-care agency to perform their ADLs. Self-care is a state of "well-being," which is defined as an important challenge for many patients (22). Erci et al. (23) found that elderly individuals with high self-care agency also had high levels of life satisfaction and hope. Lundervold et al. (9) showed that social anxiety was present in $30 \%$ of patients with ET, which was associated with tremor severity and disability.

Studies showed that higher educational levels are associated with higher self-care agency levels and that education develops positive attitudes toward health services $(19,22)$. However, no significant difference was found concerning educational level in our study, since the educational levels, including secondary school, high school, and university, were included in the same group in the analyses. In addition, no significant difference was found between gender and self-care agency in this study. However, a difference in the attitudes of men and women toward self-care according to disease groups was reported in the literature (24). The insufficient difference in our study that was interpreted as gender was not a single and strong determinant of self-care agency in ET.

This study has two important points. First, making sure that patients do not have dementia is important and that reliable answers are obtained from them, since the BDQ, SCAS, and KATZ scales/questionnaires that are used for evaluation are based on self-report answers (25). The mini-mental state inventory was administered to all patients before moving on to assessment tools to screen for dementia and exclude patients with dementia from the study. The second important aspect of the study is that it reveals the importance of self-care agency in ET. Chronic illness and deficiencies cannot be cured; however, people with chronic conditions can be helped by managing their cognition or behavior and preventing them from getting worse. 
Comparison of Disability, Self-care Agency, and Activities of Daily Living Total Scores According to Individuals' Descriptive Characteristics

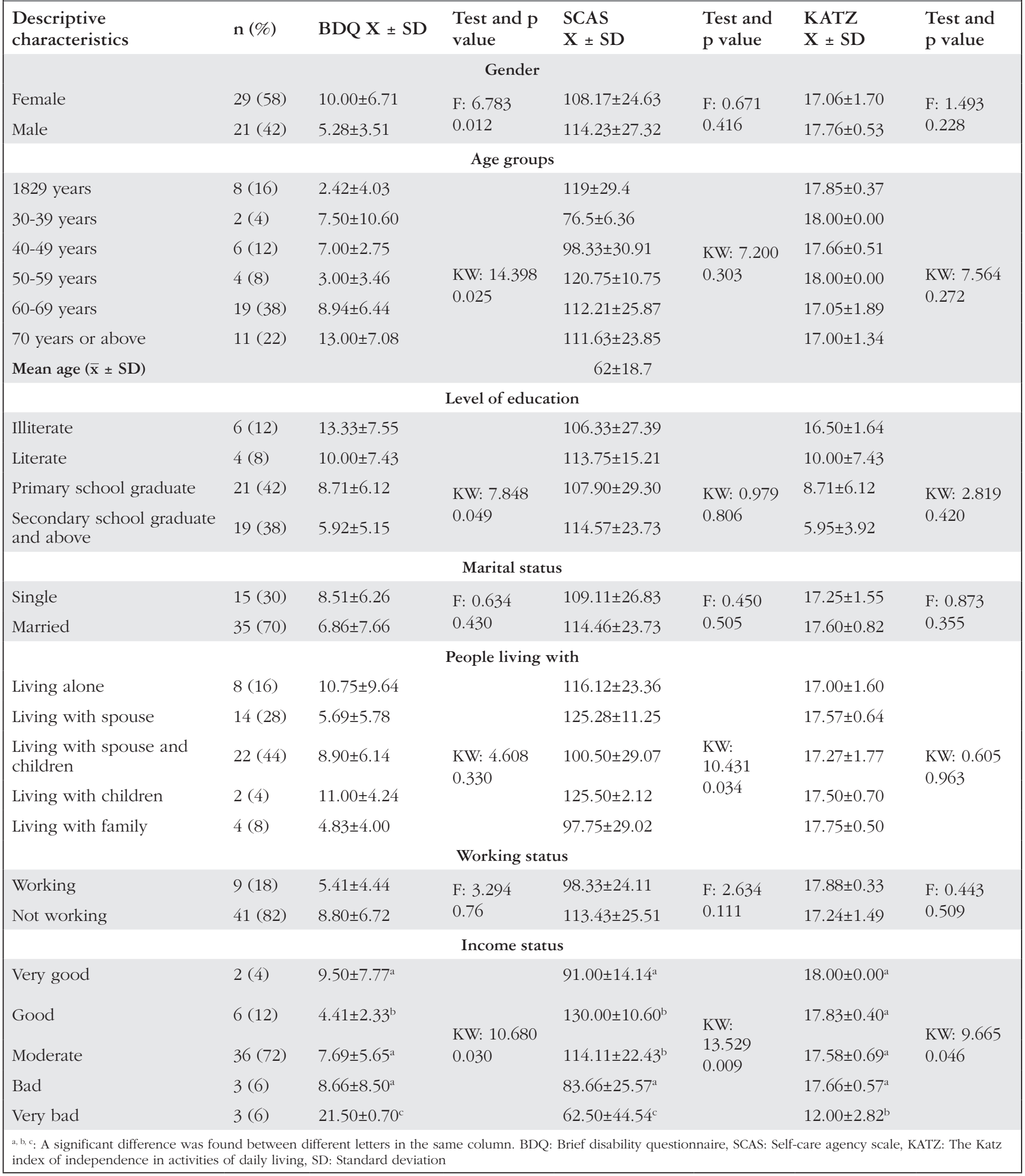




\begin{tabular}{|c|c|c|c|c|c|c|c|}
\hline $\begin{array}{l}\text { Descriptive } \\
\text { characteristics }\end{array}$ & $\mathrm{n}(\%)$ & $\begin{array}{l}\mathrm{BDQ} \\
\mathrm{X} \pm \mathrm{SD}\end{array}$ & $\begin{array}{l}\text { Test and } \\
\mathrm{p} \text { value }\end{array}$ & $\begin{array}{l}\text { SCAS } \\
\mathrm{X} \pm \mathrm{SD}\end{array}$ & $\begin{array}{l}\text { Test and } \mathrm{p} \\
\text { value }\end{array}$ & $\begin{array}{l}\mathrm{KATZ} \\
\mathrm{X} \pm \mathrm{SD}\end{array}$ & $\begin{array}{l}\text { Test and } \\
\mathrm{p} \text { value }\end{array}$ \\
\hline $\begin{array}{l}\text { The duration of the } \\
\text { tremor (years) }\end{array}$ & \multicolumn{7}{|c|}{$8.50 \pm 5.0$} \\
\hline \multicolumn{8}{|c|}{ Tremor staging (according to the Fahn Tolasa Marin tremor scale) } \\
\hline Stage I & $3(6)$ & $0.00 \pm 0.0^{\mathrm{a}}$ & \multirow{4}{*}{$\begin{array}{l}\text { KW: } 13.19 \\
0.004\end{array}$} & $124.00 \pm 9.53$ & & $18.00 \pm 0.00$ & \multirow{4}{*}{$\begin{array}{l}\text { KW: } 0.288 \\
p=0.962\end{array}$} \\
\hline Stage II & $28(56)$ & $6.39 \pm 5.45^{b}$ & & $116.67 \pm 20.39$ & & $17.00 \pm 0.68$ & \\
\hline Stage III & $18(36)$ & $11.27 \pm 6.87^{c}$ & & $98.61 \pm 31.30$ & $\begin{array}{l}\text { KW: } 4.098 \\
0.195\end{array}$ & $16.88 \pm 2.08$ & \\
\hline Stage IV & $1(2)$ & $19.00 \pm 0.00^{c}$ & & $122.00 \pm 0.00$ & & $17.60 \pm 0.00$ & \\
\hline \multicolumn{8}{|c|}{ Tremor type } \\
\hline Hand & $36(72)$ & $6.72 \pm 5.76$ & \multirow{4}{*}{$\begin{array}{l}\text { KW: } 2.914 \\
0.233\end{array}$} & $113.38 \pm 24.36$ & \multirow{4}{*}{$\begin{array}{l}\text { KW: } 1.339 \\
0.512\end{array}$} & $17.94 \pm 0.22$ & \multirow{4}{*}{$\begin{array}{l}\text { KW:0.000 } \\
p=1.000\end{array}$} \\
\hline Head & $2(4)$ & $8.50 \pm 7.52$ & & $119.50 \pm 13.43$ & & $17.50 \pm 0.70$ & \\
\hline Foot & $1(2)$ & $22.00 \pm 0.00$ & & $90.00 \pm 0.00$ & & $15.00 \pm 0.00$ & \\
\hline Other & $11(22)$ & $10.90 \pm 7.25$ & & $102.27 \pm 31.27$ & & $16.72 \pm 2.41$ & \\
\hline \multicolumn{8}{|c|}{ Disability status } \\
\hline No disability & $19(38)$ & $1.52 \pm 0.92^{\mathrm{a}}$ & \multirow{4}{*}{$\begin{array}{l}\text { KW: } 44.622 \\
0.000\end{array}$} & $121.42 \pm 18.00^{\mathrm{a}}$ & \multirow{4}{*}{$\begin{array}{l}\text { KW: } 10.887 \\
0.012\end{array}$} & $17.94 \pm 0.22^{\mathrm{a}}$ & \multirow{4}{*}{$\begin{array}{l}\text { KW: } 19.386 \\
p=0.000\end{array}$} \\
\hline Mild disability & 9 (18) & $6.44 \pm 1.87^{\mathrm{b}}$ & & $121.11 \pm 12.49^{\mathrm{a}}$ & & $17.77 \pm 0.66^{a}$ & \\
\hline Moderate disability & $9(18)$ & $9.88 \pm 1.45^{\mathrm{b}}$ & & $97.55 \pm 32.09^{\mathrm{b}}$ & & $17.00 \pm 0.86^{\mathrm{a}}$ & \\
\hline Severe disability & $13(26)$ & $17.30 \pm 2.83^{c}$ & & $97.80 \pm 28.70^{\mathrm{b}}$ & & $13.46 \pm 2.29^{\mathrm{b}}$ & \\
\hline
\end{tabular}

Table 3. Correlation between disability, self-care agency, and activities of daily living scores

$\begin{array}{lll}\text { Scales } & \text { BDQ } & \text { KATZ } \\ \text { BDQ } & - & 0.346 \\ & - & 0.045 \\ \text { SCAS } & 0.222 & 0.433 \\ & 0.121 & 0.002 \\ \text { BDQ: Brief disability questionnaire, SCAS: Self-care agency scale, KATZ: The Katz index of independence in activities of daily living }\end{array}$

From this perspective, our research on disability and self-care agency will draw attention to early evidence-based preventive interventions that can prolong the healthy lifespan in patients with ET and the elderly.

\section{Study Limitations}

Some limitations were encountered in this study. The items evaluated for SCAS and KATZ are not only affected by ultimate tremor, but also by other comorbidities that develop with age (25). In addition, the majority of the tremor type of the study participants was hand tremor. No homogeneous distribution was found. Moreover, an objective physiological measure for speech, gait, and balance disorders was insufficient. Future studies may be planned in patients with a wider variety of tremor types and severities, and the limited number of patients may be further increased.

\section{Conclusion}

Therefore, disability was determined as an important problem in individuals with ET, the level of dependency increased in ADL, and self-care agency was low. In addition, a significant relationship was obtained between disability, ADL, and self-care agency. Healthcare providers must help patients with ET to improve their $\mathrm{ADL}$ and self-care.

\section{Ethics}

Ethics Committee Approval: Permission was obtained from Erciyes University Clinical Research Ethics Committee (decision no: $2017 / 429$, date: 15.09.2017).

Informed Consent: Informed consent forms were obtained from all patients included in our study.

Peer-review: Externally peer-reviewed.

\section{Authorship Contributions}

Surgical and Medical Practices: M.G., S.B., Concept: M.G., R.B., Design: S.B., R.B., Data Collection or Processing: S.B., A.Ç., Analysis or Interpretation: M.G., S.B., A.Ç., Literature Search: M.G., R.B., A.Ç., Writing: M.G., S.B., R.B., A.Ç.

Conflict of Interest: No conflict of interest was declared by the authors. 
Financial Disclosure: The authors declared that this study received no financial support.

\section{References}

1. Louis ED, Ferreira JJ. How common is the most common adult movement disorder? Update on the worldwide prevalence of essential tremor. Mov Disord 2010;25:534-541.

2. Sullivan KL, Hauser RA, Zesiewicz TA. Essential tremor epidemiology, diagnosis, and treatment. Neurologist 2004;10:250-258

3. Whaley NR, Putzke JD, Baba Y, Wszolek ZK, Uitti RJ. Essential tremor: phenotypic expression in a clinical cohort. Parkinsonism Relat Disord 2007;13:333-339.

4. Louis ED, Benito-León J, Ottman R, Bermejo-Pareja F; Neurological Disorders in Central Spain (NEDICES) Study Group. A population-based study of mortality in essential tremor. Neurology 2007;69:1982-1989.

5. Lorenz D, Schwieger D, Moises H, Deuschl G. Quality of life and personality in essential tremor patients. Mov Disord 2006;21:1114-1118.

6. Raggi A, Leonardi M, Ajovalasit D, et al. Disability and profiles of patients with Parkinson's disease described with ICF classification. Int J Rehabil Res 2011;34:141-150.

7. Aydın ZD, Ersoy İH, Baştürk A, et al. Determinants of limitation in activities of daily living in community dwelling elderly. Geriatri ve Geriatrik Nöropsikiyatri 2009;2:9-18.

8. Şahbaz M, Tel H. Determination of the relationship between the dependence status on daily living activities and home accidents among 65 years of age and older individuals living at home. Turk Geriatr Derg 2006;9:85-93

9. Lundervold DA, Ament PA, Holt P. Social anxiety, tremor severity, and tremor disability: a search for clinically relevant measures. Psychiatry J 2013;23:481-486.

10. Lundervold DA, Pahwa R, Ament PA, Corbin DE. Validity of clinical and patient ratings of tremor disability among older adults. Parkinsonism Relat Disord 2003;10:15-18.

11. World Healt Organization. International Classification of Impairments, Disabilities and Handicaps: a Manuel of Classification Relating to the Consequences of Disease. WHO 1980, Cenevre.

12. Kaplan İ. Yarı kırsal alanda bir sağlık ocağına başvuran hastalarda ruhsal bozuklukların yeti yitimi ile ilişkisi. Türk Psikiyatri Dergisi 1995;6:169179 .
13. Kearney BY, Fleischer BJ. Development of an instrument to measure exercise of self-care agency. Res Nurs Health 1979;2:25-34

14. Nahcivan NO. A Turkish language equivalence of the Exercise of Self-Care Agency Scale. West J Nurs Res 2004;26:813-824.

15. Katz S, Ford AB, Maskowitz RW, Jackson BA, Jaffe MW. Studies of illness in the aged: the index of ADL: A Standardized Measure of Biological and Psychosocial Function. JAMA 1963;185:914-919.

16. Yardımcı E. İstanbul'da yaşayan yaşlı öğretmenlerin sağlık sonuçlarının günlük yaşam aktiviteleri ve aletli günlük yaşam aktiviteleri ile ilişkisi (Tıpta Uzmanlık Tezi). İstanbul: İstanbul Üniversitesi; 1995.

17. Fahn S, Tolosa E, Marin C. Clinical rating scale for tremor. In: Jankovic J, Tolosa E (eds). Parkinson's Disease and Movement Disorders. 2nd ed. Munich: Urban \& Schwarzenberg; 1988. p. 225-234.

18. Fahn S, Tolosa E, Marin C. Clinical rating scale for tremor. In: Jankovic J, Tolosa E, editors. Parkinson's Disease and Movement Disorders. 2nd ed. Baltimore, MD: Williams \& Wilkins; 1993;225-234.

19. Tanimura C, Matsumoto H, Tokushima Y, et al. Self-care agency, lifestyle, and physical condition predict future frailty in community-dwelling older people. Nurs Health Sci 2018;20:31-38.

20. Soysal P, Veronese N, Thompson T, et al. Relationship between depression and frailty in older adults: A systematic review and meta-analysis. Ageing Res Rev 2017;36:78-87.

21. Jang IY, Jung HW, Lee CK, et al. Rural and Urban Disparities in Frailty and Aging-Related Health Conditions in Korea. J Am Geriatr Soc 2016;64:908911.

22. Basak T, Unver V, Demirkaya S. Activities of daily living and self-care agency in patients with multiple sclerosis for the first 10 years. Rehabil Nurs 2015;40:60-65.

23. Erci B, Y1lmaz D, Budak F. Effect of self-care ability and life satisfaction on the levels of hope in elderly people. J Psychiatry Nurs 2017;8:72-76.

24. Riegel B, Dickson VV, Kuhn L, Page K, Worrall-Carter L. Gender-specific barriers and facilitators to heart failure self-care: a mixed methods study. Int J Nurs Stud 2010;47:888-895.

25. Hariz GM, Blomstedt P, Koskinen LO. Long-term effect of deep brain stimulation for essential tremor on activities of daily living and healthrelated quality of life. Acta Neurol Scand 2008;118:387-394 